\title{
The Rhetoric of Martyrdom and the Anti-Nicodemite Discourses in France, 1550-1570
}

NIKKI

SHEPARDSON

Résumé : L'expression du martyre et de la souffrance a marqué et défini le mouvement de réforme qui a eu lieu en France au seizième siècle. Ce langage a servi à unir la collectivité, à réécrire et à réinterpréter l'histoire et à former la mémoire collective. Mais si le martyre a valorisé la collectivité, le nicodémisme l'a minée. Cette étude soutient que pour saisir la controverse nicodémiste, il faut l'examiner sous l'angle du martyre. D'ailleurs, dans les textes antinicodémistes, qui manifestent clairement cette rhétorique, on retrouve le vocabulaire, les images et les symboles du martyre.

$T^{n}$ the prefatory epistle to his 1563 martyrology, Antoine de la Roche 1 Chandieu told his readers that within the pages of his work,

Some will recognize here the brothers and comrades who were torn from their company to be cruelly put to death: wives will find their husbands here, fathers their children, and children their fathers, tortured and murdered on account of the word of God. Others will see here the time of their imprisonment or of what followed. Others will hear here of their losses, the theft of their possessions, and the desolation of their families. ${ }^{1}$

In acknowledging these connections, Chandieu drew his readers into the realm of the martyrs, creating bonds between the living and the dead, merging all those who were persecuted into a community. The readers recognized their own world within the various accounts and identified in some way with the martyrs' experiences. Such a connection reinforced the idea that all followers of the Reformed faith suffered for and were bound by a common cause: loyalty to the "word of God."

The persecution in France generated two major martyrologies: Antoine de la Roche Chandieu's Histoires de Persécutions, et Martyrs de 
l'Église de Paris, depuis l'An 1557. jusques au temps du Roy Charles neufviesme (Lyon, 1563), and Jean Crespin's Livre des martyrs (1554). While these collections held the martyrs as examples of correct behavior in the face of persecution, they also described the persecution and ensuing martyrdoms as evidence of God's favour and aid. Within the pages of the martyrologies, the martyrs' faithfulness served to edify the community. But most importantly, the martyrs' public professions of faith, which displayed their convictions above all worldly ties, strengthened and emboldened the "cause" and the new community in its struggle to survive and grow.

Just as the martyrs performed these services, drawing together and embodying this community of suffering, the Nicodemite undermined it. Theodore Beza described the phenomenon of Nicodemism as a result of the persecution:

At this time also there were some persons in France, who, having fallen away at first from fear of persecution, had afterwards begun to be satisfied with their conduct as to deny that there was any sin in giving bodily attendance on Popish rites, provided their minds were devoted to true religion.... The consequence was that from that time, the name of Nicodemite was applied to those who pretended to find a sanction for their misconduct in the example of that most holy man Nicodemus. ${ }^{2}$

The Nicodemite, then, was the antithesis of the martyr. As the French crown stepped up its persecution of the Huguenots after 1540, the issues of martyrdom and Nicodemism became prominent topics in the works of many reformers.

In the writings of Jean Calvin and Pierre Viret, the Nicodemite and the martyr were juxtaposed. Whereas the martyr was praised as a mirror in which the faithful saw amplifications of their own suffering as well as the triumph of God's cause, the Nicodemite was excoriated as a saboteur. The Nicodemite, then, was a type of anti-martyr whose actions subverted rather than supported, disheartened rather than consoled. The Nicodemite remained silent while others testified, clinging to earthly pleasures and fears rather than transcending them and fulfilling the responsibility to God. Thus, not only was the Huguenot community threatened without by persecution from the state and popular violence, but it was also, according to some reformers, threatened from within by the "perfidious" Nicodemites. ${ }^{3}$

This article examines how the general rhetoric of martyrdom, and its expression in the anti-Nicodemite texts, functioned to create and support a communal identity for the Huguenots prior to the St. Bartholomew's Day Massacres of 1572. It also investigates how the issue of Nicodemism, as it 
was treated by the leaders of the religious reform movement, especially Calvin and Viret, reveals more than a concern for the fate of individual souls. The spiritual health and cohesion of the community was at stake. Thus they infused a type of social consciousness into the choices confronting the Huguenots in France.

The debate over Nicodemism is multifaceted. The purpose of this essay is not to analyze the level of Nicodemism in the Huguenot community, or its origins, or the varying attitudes of reformers, or even the response of the community to the reformers, all of which have been the focal points of previous studies. ${ }^{4}$ While the history of Nicodemism has been addressed by many historians, the positioning of the anti-Nicodemite discourses within the larger rhetoric of martyrdom has been glossed over or neglected. Most historians have done the opposite, placing the rhetoric of martyrdom within the anti-Nicodemite discourse. This has had the effect of taking Nicodemism out of the larger context of the literature of persecution, and isolating the Nicodemite from its counterpart, the martyr. This study argues that to understand the Nicodemite controversy, it must be placed within the larger rhetoric of martyrdom. While some of the analyses describe the option or representation of martyrdom in the discourses, they do not look at the ways in which the anti-Nicodemite texts use some of the same language, symbols, and images of the larger rhetoric of martyrdom, and indeed are vivid manifestations of this rhetoric.

Instead, by examining the links between the anti-Nicodemite discourse, community building or defending, and the general rhetoric of martyrdom, this essay addresses an aspect of the Nicodemite controversy that has been overlooked by many of the historians who have approached the subject. For example, though William Bouwsma touches on the connections when he notes that "His [Calvin's] insistence on the church as a functioning community was closely related to his rejection of what he called 'Nicodemism'. ..," his analysis goes no farther. ${ }^{5}$ Other authors discuss the connections between rhetoric of martyrdom and the anti-Nicodemite literature. Peter Matheson's insightful article analyzes the reformers' varying degrees of advocating martyrdom vis-à-vis Nicodemism in building and defending the Church. However, Matheson's discussion neglects the prominent role that the rhetoric of martyrdom plays in defending the Church or community against Nicodemism. Carlos Eire's War Against the Idols alludes to the threat Nicodemism posed to the Protestant cause (i.e. community), but martyrdom appears tangential to his analysis, relegated to being one possible repercussion of "steadfastness: the other alternative."6 
In a different approach, a comprehensive and comparative treatment of the martyrologies, Brad Gregory rejects a linkage between anti-Nicodemism and martyrdom in the minds of the Huguenots as not being "part of a collective Protestant mentalité." I agree that there was much resistance to Calvin's seemingly unrealistic demands and that many would abjure when pressured. The lack of constancy, however, does not preclude recognition on the part of the Huguenots of a connection between anti-Nicodemism and martyrdom. In other words, to choose a more pragmatic faith is not to reveal a lack of awareness or a complete rejection of martyrdom. It only illustrates an inability or unwillingness to embrace such an extreme sacrifice.

The martyrologists and reformers, Calvin most notably, describe martyrdom as an election-a gift and ability granted by God-and not possible for everyone. Martyrdom was not advocated for all. And while martyrs were anti-Nicodemites, anti-Nicodemism was not necessarily a whole-hearted embrace of martyrdom. Martyrdom was an ideal: the act of the martyr was not for everyone, but all could attempt to embrace or incorporate the qualities described by the martyrological accounts and not be a Nicodemite. Herein lies the linkage. Not only was the connection in the literature, in examples placed directly in front of the faithful, but in all likelihood this linkage caused great discomfort. Hence, the desire to see and embrace areas of grey does not preclude the association of martyrdom with anti-Nicodemism in the mind-set of the Huguenot. The two issues were intrinsically linked through the rhetoric of martyrdom that pervaded most aspects of literature aimed at the persecuted French Protestants.

This serves to highlight a more important difference in approach between Gregory and myself. Whereas Gregory emphasizes the importance of the individual conscience in the choice to embrace martyrdom, I would argue that the communal component of martyrdom is just as important in terms of the aims of the martyr. For example, as discussed below, the letters written by the martyrs reveal a recognition that their sacrifice did not simply serve God but served the community of the faithful as well. Indeed, the community should share in the experience of the martyr. Many martyrs specifically stated that the purpose of their letters (including accounts of their interrogations and imprisonment) was for the "edification" and "consolation" of their brethren. One martyr went so far as to state in a letter that "I say Our [emphasis his] captivity, because you come to feel mine and I yours: for all good and bad are common among brothers." 8 The frequency with which the martyrs asked family members and friends to publicize their letters also reflects the communal concern and responsibility felt by the martyrs. The martyrs saw themselves not only as creatures 
of God, but as instruments for the community in the sense that they (through their acts and words) provided consolation, edification, and inspiration to the faithful; in other words their responsibility was to God but also to the community.

The creation of the Huguenot community and communal identity were intrinsically tied to the shared experience of persecution and suffering. Thus the perceived threat to the community by those who undermined this identity by avoiding or advocating avoidance of this experience should be recognized. It was the rhetoric of martyrdom that forwarded this interpretation of community in its profoundest expression. Just as the advocacy of martyrdom as the ideal model and source of edification (and even augmentation) for the faithful is a sub-current in the anti-Nicodemite texts, so is the recognition of the particular threat posed by the Nicodemites.

\section{Creation of Community: Suffering, Sacrifice, and Faith}

At the heart of the effort to define and defend the increasingly besieged Huguenot community, post-1540, was the rhetoric of martyrdom. Just as religious persecution underwent a large scale renaissance with the advent of the Reformation, so did martyrdom and its accompanying forms of the literary genre of martyrology and general rhetoric of martyrdom. This rhetoric employed many of the same images used by ante-Nicean fathers Origen and Tertullian, such as the martyr as champion or warrior of God, and the martyr as an imitator of Christ and inheritor of his suffering. ${ }^{9}$ Their language of sacrifice as well as that of disdain for the worldly found resonance once again in the situation confronting the Huguenots. Origen especially reminded his readers that every earthly tie - be it wealth or family - must be hated and rejected in favour of upholding God's truth. This sacrifice, as described by both fathers, would be rewarded hundredfold in the kingdom of God. Once cited by Origen and Tertullian as a clarion call for martyrdom, Matthew 10:37-3910 found champions once again among the Protestant reformers and martyrologists. ${ }^{11}$ It was this rhetoric that would be rediscovered and employed once again in the struggle against persecution.

The language and imagery of martyrdom, however, were not confined to the martyrologies. Along with the compilations of Chandieu and Crespin, numerous pamphlets were produced from both theological and political perspectives utilizing a rhetoric of martyrdom, including the anti-Nicodemite texts. While not always referential to the martyrs, the language and symbolism found in these pamphlets nevertheless fostered the same values embodied by the martyrs: sacrifice, suffering, constancy, 
responsibility to both God and the community of the faithful, and the primacy of the soul over the flesh. The rhetoric served to console and unite the faithful, and at the same time it defined their world view vis-à-vis persecution.

As a way of both defining and defending the purity of the community, multiple treatises and sermons were produced by reformers, especially from the 1540s through the 1560s, advising "the faithful man" ["l'homme fidèle"] how to live virtuously among the "papists" and castigating idolatry as an "infection" or "pollution." 12 Understandably, pollution by idolatry is a prominent theme in these prescriptive and defensive works attacking the rituals of the Catholic Church. ${ }^{13}$ Reformed writers, like the Catholic polemicists, spoke of the threat of divine communal retribution if idolatry was tolerated. ${ }^{14}$ Reformers recognized the communal repercussions of both abstention from or participation in these rituals. For example, Calvin wrote, "Nothing is more infectious than association with the ungodly ... especially when there is danger of idolatry." 15 In another example, in his Petit Traicté monstrant que c'est doit faire un homme fidèle, Calvin used the instance of the death of a father, neighbour, or friend to argue against performing acts of idolatry. He pointed out the sinfulness of appearing to pray for the soul of the deceased; of going along with the others to do so. Even more so, it would be wrong, and here he used the example of a deceased family member such as a wife or father, to pay for a mass. ${ }^{16}$ In using these examples, Calvin was referring to the traditional bonds within a community and the traditional mechanisms by which these bonds are expressed. Abstention from the offending idolatry in these instances threatened that community. And by using such examples, Calvin aimed at the heart of the issue: a faithful man must break with the old community, including family, if it supports idolatry.

With the destruction of traditional ties came an effort to establish a new community based on a different collective self-consciousness and according to the needs and requirements of the new faith. The anti-Nicodemite works of Calvin and other reformers offered the blueprint for this new community, one untainted by idolatry and that would correctly worship together the true word of God. While the old institutions of Catholicism that expressed and supported community were to be excised from the new community, the survival and solidarity of the group still depended on outward expressions of faith. Though theologically it was the individual's relationship to God and not reliance upon ritual or outward acts that defined the path to salvation, Calvin and others expended much ink on the importance of outward expressions. The predominance of the invisible Church of Luther had for the most part given way in Calvin's thought to the visible 
Church on earth. ${ }^{17}$ Many reformers encouraged and insisted upon attendance at assemblies where sermons were given, the Lord's Supper reenacted, and psalms sung. ${ }^{18}$

On a more rhetorical level, Calvinist reformers often cited Matthew 10:37-39. ${ }^{19}$ Hence, the new community was based not only upon a shared religion but also upon a rhetoric of sacrifice and responsibility to God. A cornerstone in this building effort was the issue of martyrdom. While martyrdom has been described as "an assertion of individuality against the family and community," 20 this argument fails to identify the community which the martyr reaffirms, edifies, consoles, and bonds together through his suffering and example. While it applies to the former connections of the martyr, it overlooks the communally creative aspect of the rhetoric of martyrdom.

On an ecclesiastical and social level, the notion of "congregation" linked the Huguenot community. ${ }^{21}$ However, during the years prior to the outbreak of the civil wars, from the late 1530 s through the late 1550 s, the identity of the "community of suffering" served to bond the community on a psychological level. The "suffering of the faithful" became a description that occurred in almost every sermon, treatise, or pamphlet written by a Reformed hand. At the heart of this reference was the dictum found in Crespin's prefatory Epistle, that "Among the signs by which the true Church of God is known, it has been one of the principal ones, that she has always endured the attacks of persecution." 22 Suffering marked them as God's chosen, thus legitimating the "cause." And it was here that the martyrologies and martyrological narratives functioned best.

The purpose of the martyrologies and martyrological narratives was not simply to recount individual martyrdoms; much more broadly, their aim was to respond to the needs of a fledgling community struggling for their existence and sense of identity. A particularly important expression of this can be found within the martyrological accounts: the letters written by imprisoned martyrs and sent to individuals or particular churches with the expressed purpose of wider dissemination. These and many other open letters to the Church reflect the awareness of the martyrs that their experience was not simply their own, but should be the spiritual "property" of the community in general. This suggests the perception that the road to martyrdom should not be travelled alone, but shared and benefitted from by all. For example, martyr Pierre Bergier (d. 1562), in a letter to his wife, instructed her to gather all his correspondence: "You will be able to distribute the said letters to many people so that the Church may gather a greater harvest from them." 23 Another example is found in the account of martyr Richard Le Fevre (d. 1564). Crespin, as editor, provided a brief 
introduction to Le Fevre's letters, stating, "We have published his letters here so as to share them with all of the faithful." 24 In one of these letters Le Fevre alluded to the reason for sending along information about his interrogation: "I shall report some of it, assuming that you don't ask for it out of curiosity but only for the building of the Church." 25 The martyrs' experiences, as they themselves perceived it, consoled, encouraged, and educated their audience - the entire community of believers, whose faith marked them as God's chosen. ${ }^{26}$

In the formation of the new community, the martyrology fulfilled the role of a depository for the memories of its community - the memories of persecution and victory that helped shape its identity. Even more so, the martyrology served to define and shape the collective experience. It "furnish[ed] that sense of solidarity which is the prime essential of maintaining a group consciousness which has recently been achieved but which is in danger of disintegration." 27 Part of this group consciousness was the construction of the idea of a shared past, both recent and ancient, that reinforced the legitimacy of the movement. The martyrologies, then, were created as histories functioning in the same way as Eusebius's Ecclesiastical History, tracing the foundations of the church that were built with the blood of the "righteous." These histories identified the Protestants as God's chosen ones. They were part of a continuum, with persecution serving as God's mark. The examples of the Israelites, whose election by God and suffering are compared to the modern faithful, and of the early Christian martyrs, who are the spiritual ancestors of the persecuted community, are plentiful in the works of both Crespin and Chandieu. ${ }^{28}$ Though the Israelites were condemned and punished for their temporary fall into idolatry, the identification with them nevertheless served to form the impression of a type of "super-community" of God's chosen, all of whom have suffered persecution. 29

Outside of the martyrologies, references to this "super-community" of sufferers exist in numerous places. One example is in Heinrich Bullinger's sermon "De la fin du siècle, et du jugement à venir de notre Seigneur Jesus Christ." Bullinger traced a history of the chosen ones, beginning with the persecution and enslavement of the Jews in Egypt, through the martyrdoms of the early Christians, up to the reign of the papacy which has engaged in "perpetual ambushes, cheating and torments." Through tracing this lineage, Bullinger raised the ante for Protestants as he lists out the years of persecution: 200 years for the Jews in Egypt and 70 under the Babylonians, 300 years for the early Christians under the Romans, but 700 for the Church under the dominion of the papacy. ${ }^{30}$ Thus, he elevated the Protestants in terms of their suffering in relation to their predecessors. 
As much as the notion of shared suffering identified this community, the construction of a shared history gave this new community grounding and a communal past from which they all might draw. The separation of the Catholic version of the history of the Church from the Reformed view was essential to this purpose. The Calvinist movement then needed to re-conceptualize the history of the Church. An essential part of this history was martyrdom, and while the Reform movement reclaimed and appropriated both the early Christian martyrs and martyrdom itself, it presented them both in a new light. Both Crespin and Chandieu referred to the early martyrs but explain how the Catholic Church corrupted their accounts. Both martyrologists then offered corrections restoring the martyrs to "the correct practice" ["leur droit usage"]. ${ }^{31}$ An additional example of the reconceptualization of history is found in the French translation of 1564 of Tertullian's Letter to the Martyrs. The translator and editor, Jean Saugrain, wrote in his prefatory Epistle that the age of confessors, as defined by the Catholics, never occurred and that the age of martyrs never ended, as the true church is always persecuted. 32

Up to this point, I have focused primarily on the ways in which the community was defined and identified through their collective suffering. There was, however, in the rhetoric of martyrdom from the 1560s onward, an increasing reference to the community as bound together as warriors of Christ. ${ }^{33}$ As the French Wars of Religion escalated after 1560, the rhetoric of martyrdom shifted from a passive form, of a didactic and emulative nature, to a rallying call. God was now called upon to avenge the blood of the innocents, ${ }^{34}$ and the prayers written for the Huguenot soldiers exhorted them to fight to the last drop of blood; to prefer death over the shame and humiliation of a betrayal of conscience. 35

Again, at the heart of this particular rhetoric were the martyrs, the "valiant champions, who have been through their battles, and by their death surmounted all afflictions, who are remarkably useful and necessary." 36 Whereas martyrs had been described occasionally prior to 1560 as "champions" of God-individual warriors who fight for His cause very much in the image of the medieval champion representing his king - this martial imagery began to be applied to the community in general, even by the martyrs themselves, sometime around 1560. The combat of the martyr became the battle of the faithful. For example, martyr Claude Monier (d. 1561) addressed his brethren:

Up, then, my warrior comrades, to the attack! Courage, soldiers, courage! March hardily! Do not fear them! They are not people for us, for Jesus Christ our captain has defeated them all. The hope for His victory will serve to arm our head. Let us 
not forget our shield, which is to have a living faith, powerful and virtuous, to ward off the blows of our enemies. Watch lest the sword slip from our hands, this blade of the Holy Spirit that cuts on both edges, which is that living word of God that pierces hearts and souls and thoughts and intentions. ${ }^{37}$

In another letter, martyr Geoffry Guerin (1558) wrote: "under the protection and defense of [the Church] we must all fight, like true champions and soldiers faithful to our captain." 38 The reformers also referred to the community in terms of this martial imagery. Jean L'Espine exhorted:

Let us also realize that it is not a great honor for a Christian if, when he departs this world to return to Heaven to see his Father, he does not bring Him his shield, which is faith, and his lance, which is the word, and all the rest of his arms, red and stained, both with his own blood and with that of the enemies of the Church, for there is no order of knighthood more beautiful. ${ }^{39}$

This image of the community existed concomitantly with the "community of suffering," which, like the martyrs, did not lose its significance or efficacy even as the Huguenots went on the offensive in the civil wars. Nevertheless, as the movement became increasingly frustrated, culminating in the Conspiracy of Amboise (1560) and the outbreak of open war in 1562 , the "community of suffering" underwent a subtle transformation from passive endurers to active militants on a number of levels.

Whether united in suffering or battle, the identity of the community of the faithful was defined through the rhetoric of martyrdom. The survival of this community depended on its solidarity and the outward expressions of faith that bound it together. The martyrologies and martyrological narratives provided exemplars for the community and created both a new vision of the past and a social memory. They united the persecuted and victorious martyrs with the living community, and provided a common bond among the faithful. This was a community whose fate depended not only on the physical survival of its members but also on their unambiguous adherence to the doctrines of the faith-regardless of the consequences.

\section{Anti-Nicodemism and Community: Calvin and Viret}

A relationship exists between the martyrologies and the anti-Nicodemite discourses. Not only did they both present martyrs as exemplars of proper behavior, ${ }^{40}$ but they also addressed similar issues and concerns: offering consolation and instruction to those living in hostile territories, extolling the triumph of the soul over the desires of the flesh, emphasizing the importance of oral confessions of the faith, and defining the community of the faithful and their responsibility to God. In essence the anti-Nicodemite 
texts use the same language of responsibility and sacrifice, of creating a separate community based not upon the traditional ties of parish and family but upon the cross that the faithful must bear as God's chosen. They had a responsibility to God to uphold the cross unambiguously and to confess the faith even while suffering persecution:

The avoidance of this cross, in the form of Nicodemism, had repercussions within the community of the faithful, according to Calvin and Viret. This avoidance and its impact on the community became the topic of numerous treatises written in the vernacular by them (e.g. intended for a popular audience) beginning in the 1540s, the period in which the French state began its active pursuit and persecution of Protestants within its boundaries. ${ }^{41}$

These reformers imbued a type of social consciousness in the choices made by the faithful in light of the negative repercussions, as they perceived them, brought upon the community by the actions of the Nicodemites. In other words, just as the rhetoric of martyrdom created a sense of community among the faithful, the anti-Nicodemite treatises reflected a concern for this community, calling upon its members to acknowledge their responsibility not only to God but to the community itself when negotiating the hazards of persecution and living "among the papists."

The Huguenots had three choices when confronted with persecution: going into exile, remaining and risking martyrdom, and dissimulating (i.e. "playing the good Catholic"). ${ }^{42}$ Exile meant the loss of goods, property, and possibly family, while death or imprisonment could result from remaining and openly professing the faith. Nicodemism, then, appeared to be a pragmatic option. Nicodemite arguments, as described by Calvin and Viret, supported simulation on a number of grounds. ${ }^{43}$ The major justification for Nicodemism involved the distinction between inner intention and outer conformity. External adherence to Catholicism mattered little if interior faith (e.g. Calvinist) remained true. This would justify attendance at Mass or other "idolatrous" behavior. By externally conforming while remaining faithful in one's heart, the Nicodemite could avoid suffering persecution. Calvin's and Viret's attacks point to a second important Nicodemite argument that dealt with the very real survival of the church in France: by staying underground and not exposing themselves to persecution and martyrdom, the church could continue to grow and strengthen rather than be decimated.

Whereas both Calvin and Viret expressed sympathy for the suffering of the French community and their situation, they both nevertheless demanded that the faithful abstain from idolatry in any form, whether through removing oneself from the territory or refusing to participate in any 
Catholic rites or rituals. While Calvin was not the first reformer to write on the subject, he was certainly one of the most prolific. ${ }^{44} \mathrm{He}$ spent a great amount of time on this issue from the 1540s on, coinciding with the stepped up persecution of Protestants in France. ${ }^{45}$ Indeed, almost all his work on the subject addressed the Huguenots.

It is in the Excuse de Jehan Calvin that Calvin first used the term "Nicodemite," though in this work he used many of the same arguments and images as he does in the earlier Petit traicté. Here Calvin refined his definition of Nicodemite, breaking it down into four categories. (Previously, in the Petit traicté, he had broadly defined those whom he would later call Nicodemites as those who "simulate.") His four main types consisted of false evangelists who claim to preach the gospel, but are concerned more for their positions; ${ }^{46}$ evangelists at court, and the ladies that patronize them, who take the Gospel too lightly; ${ }^{47}$ those who treat Christianity as a philosophy; and, finally, the common folk and merchants who dissimulate out of fear and weakness of the flesh. ${ }^{48}$

Viret's most comprehensive work on anti-Nicodemism is a collection of five treatises entitled Traitez divers, published in 1559, consisting of one original and four previously published treatises. ${ }^{49}$ His definition of the Nicodemite was less precisely outlined than Calvin's, and the "sin" more sympathetically presented. Viret divided the Nicodemites into two categories: those who mislead purposely, and the commoners who fall prey out of weakness. Viret referred to the former as "advocates and procurers," 50 who have created a "pernicious doctrine" and lead men astray through sly arguments. ${ }^{51} \mathrm{He}$ essentially equated them to Satan or servants thereof, who convince men that dissimulation is but a small sin. 52

While Calvin saw no difference in degree or sinfulness among his Nicodemites, Viret reserved his vitriol for those who preached Nicodemism, and his pity for those who succumbed. Viret was much more understanding and less judgmental than Calvin toward the common folk who "succumb to the weakness of the flesh." Viret himself questioned whether he would be able to remain constant if he lived under the same conditions as the persecuted Huguenots. ${ }^{53}$ And unlike Viret, Calvin's black and white stance on the issue earned him accusations of being unreasonable and unsympathetic from both his sixteenth-century audience and modern historians. ${ }^{54}$

Regardless of the differences in the degree of sympathy they expressed, both reformers expended much ink and time to counter $\mathrm{Ni}$ codemite arguments. Whereas Calvin's works after the Petit traicté were chiefly attacks on Nicodemism, Viret's were more consolatory and instructional; but his message was no less uncompromising or demanding than 
Calvin's. His sympathy was for the suffering, but it did not extend to the excuses and arguments put forth by Nicodemites (especially those who preached compromise from the pulpit) which he refuted with all the vehemence expressed by Calvin. The severity of their admonitions and the sheer number of pages they dedicated to the issue testifies to both their frustration and the pervasiveness of Nicodemism. ${ }^{55}$

The number of anti-Nicodemite treatises aside from Calvin's and Viret's is quite large, the most important of these being Le Temporiseur (originally published in Latin in 1549 as Proscaerus, then in French in 1550), by Wolfgang Musculus. Its four dialogues addressed the main arguments of Nicodemism, namely conformity out of fear. The text was reproduced in numerous editions and languages. ${ }^{56}$ The French translation contains an important anti-Nicodemite collection: the pamphlet Conseilz et Advis de Plusieurs grands \& doctes personnages sus la même matière contenue au précédent Livre du Temporiseur (published independently in 1565), comprised of numerous epistles and excerpts from previously published antiNicodemite tracts that offer consolation and advice. The contributors include: Oecolampade, Melanchthon, Bucer, Peter Martyr, Calvin, Simon Sultzer, Jean Lason, Bernardin Ochim, Celius Secondus, Viret, Martin Borrahus, Oswald Mycone, and Zwingli. Nicodemism was of great concern, then, to a number of reformers. Each reformer advocated the same uncompromising stance on the importance of oral confessions of faith and abstention from idolatry. It is important to note here that the editor of the Conseilz et Advis, Jean Saugrain, was also the editor of the French translation of Tertullian's To the Martyrs and Letter to Scapula.

Nicodemism troubled these reformers on numerous levels. The threat Nicodemism posed to the individual's soul was of great concern. Viret especially paid much attention to the suffering of individuals, and to how fear and pain could lead to Nicodemism. But even here, both Viret and Calvin pointed out how the weakness of an individual could threaten the community as a whole. Both reformers wrote considerably on the individual's responsibility to God and the rewards that would be attained for faithfulness, and concomitantly the spiritual penalties for idolatry. However, the survival of the Reform movement in France hinged upon the resolve and congregational discipline of the community. Hence from 1540 on, the community of the faithful, not just the individual believer, became a focal point for the leaders of the Reform as the Huguenot struggled for survival.

Calvin and Viret had similar interpretations of what the community was, and its significance. On a practical level, Calvin saw "community" in its traditional sense: made of neighbours and households. 57 While this 
interpretation held true in areas like Geneva, where the faithful could live and worship together without the pressure of persecution or the yoke of a Catholic state, it did not serve well the community in France. There, his association of the "community" with the "church of the faithful" was more applicable. ${ }^{58}$ Calvin and Viret both insisted on the separateness of this community from that of the idolaters, and the maintenance of its purity. Hence, the community in France for both reformers was based on faith: the community was the faithful. Calvin and Viret emphasized the importance not just of the individual worshipping God properly, but also of the entire community. This, Calvin claimed, was his intention in writing on Nicodemism: "For I can truthfully protest, before God and his angels, that my intention is no other than to obtain, insofar as I am able, that we should all serve God together purely."59

The proper edification of the community was a theme expressed throughout both reformers' texts on Nicodemism. Each member of the community had a responsibility to provide a good example for their neighbour. "It is to give no cause to our neighbour to be displeased with us, to give him no poor example, and to neither say nor do anything that would corrupt him." 60 This example involved confessing the faith and avoiding idolatry in any form. Both reformers postulated that proper worship and confession of the faith by individuals had a positive impact on the community, thus fortifying it. ${ }^{61}$

The Nicodemite, on the contrary, provided a bad example for the community, infecting it with "a venom so powerful and so dangerous that one must draw back from it as far as possible." 62 One particular type of Nicodemite not only infected them, but actively tried to corrupt them and so lead them into the same sin: "Moreover he moves us to induce others to dissemble." 63 Calvin also described these particular simulators as bad influences on the community, as they "induce others, by their example, to idolatry." 64 Both Reformers, then, refer to Calvin's first type of Nicodemite (or according to Viret a type of "Satan"): those who claim to preach the Gospel, but nevertheless cling to idolatry.

There is also the example of those within the community who dissimulated by attending Mass and thus induced others by their example to do the same: do they think that "they do not scandalize the weak, by giving them a poor example or by giving them doubts and scruples that they do not know how to resolve?"65 In an analysis of 1 Corinthians, Calvin discusses how Paul relates the communal impact of someone who "quibblingly pretend[s] innocence of conscience" and commits idolatry so that 
they invite them [neighbours], by their example, to do the same things; and they do them, not because they understand them to be lawful, but because they see an authority in the individual whom they imitate, though he is acting not only with a doubtful, but an opposing conscience. ${ }^{66}$

It was through such passages as these that Calvin instilled a communal dimension into the choice made by the individual. Calvin believed any Nicodemite behavior on the part of individuals to be just as detrimental to the health of the community as that of those who actively proselytize its arguments. But it was not just the community's spiritual soundness that was threatened by dissimulation. The wrong choice by an individual could also jeopardize the communal, physical well-being by provoking God's ire upon both the righteous and idolaters together: 67

And it is no small thing to give a poor example to one's neighbours, to confirm the ignorant in their error and to trouble the weak or to scandalize them. But when with all this we add an impudence, and like shameless whores we set our own mouths on fire in order to say that we have done nothing wrong, that is to despise God openly and as if with deliberate intent to provoke Him to combat, and to arm Him to take His vengeance on us. ${ }^{68}$

The individual then had a responsibility beyond his own salvation to the welfare of them all.

The physical threat to the community posed by the Nicodemites took on another form in the thoughts of Calvin and Viret. According to Viret, the Nicodemite, in going along with the idolaters, not only posed a bad example for the faithful but also confirmed the "idolaters" (Catholics') superstitions and hardened them in their errors by not showing them the right way. ${ }^{69}$ In doing so, the Nicodemite betrayed the faithful, condemning them to further persecution, and even causing the deaths of others:

And what is more, we [who might embrace Nicodemism] inflame the fury of tyrants, and we betray our brothers, and we are oftentimes the cause that they are put to death. For if we were to declare ourselves openly, or at least if we did nothing to approve the false religion of the idolaters, we would sow confusion among them, where now we confirm them in their error and tyranny and arm them with our authority against our brothers. ${ }^{70}$

Calvin described this issue a bit differently and less clearly. Though the Nicodemites might not bring down persecution upon themselves, "they nourish all idolatry with their dissembling, become the reason that the necks of some men are broken and that others are wounded grievously, and that some are butchered and others are lamed, or stray from the right 
road." 71 The decision to simulate, then, was infused with responsibility for the physical harm of others.

Calvin also countered the argument put forth by the Nicodemites that they simulate so as to lessen the danger of persecution and help the Church to grow, otherwise it will perish. Calvin argued that if we all simulate as they do, "the countries where God has planted many seeds would remain a desert." 72 In other words the seed of the church, the martyrs, who cause the church to grow, will cease to be produced, and the church will fade. Calvin and Viret contrasted the constancy and sacrifice of the martyr with the "scandalousness" of the Nicodemite. ${ }^{73}$ Just as the martyr is the source of augmentation of the faith, they argued, the Nicodemite will cause it to decrease. In equating the situation of the early Christians to that of his time, Viret admonished, "If they had been as afraid for their skins as we are, the Christian religion would not have grown so much in so little time." 74 Calvin also argued that without the early Christian martyrs' willingness to suffer, and to withstand Nicodemite arguments, there would never have been a Christian Church. ${ }^{75}$

The forbearance of persecution and suffering in the name of the Gospel was a prominent theme in both the martyrological accounts and the antiNicodemite texts. This "cross," which defined the community as chosen by God, was rejected by the Nicodemite. Both Calvin and Viret agreed to some extent with the Nicodemite argument that if God sends persecution, then it must be borne in patience, but it is good to avoid it as much as possible. However, both reformers qualified this. Viret associated some suffering and sacrifice with the believer's responsibility to God: that to be a true Christian one must endure. To support this argument he cited Luke 14: "And he who would like to be my disciple must renounce himself and he must carry every day His cross on his shoulders, and he must follow me." 76 The willingness to suffer for God's truth was essential to being a good Christian.

Calvin's strongest assertion of this theme can be found in the second of the Quatre sermons, "Exhortation à souffrir persecution pour suyvre Iesus Christ et son Evangile." The corpus of the Quatre sermons is essentially an anti-Nicodemite text, exhorting the faithful to avoid idolatry in the first sermon, asserting the importance of external worship and church discipline in the third, and extolling the privilege to hear freely the Gospel preached (i.e. an argument for exile). The second sermon, however, is a specific argument for the responsibility of the faithful to endure suffering if it means upholding God's honour in the face of idolatry and superstition. Calvin, like Viret, described the path that Christians must tread to be full of suffering: 
Although it may seem rough to us at first glance, we must content ourselves with this word of Saint Paul (1 Thess. 3:3) that we are called upon and created to suffer, since he said that the condition of our Christianity is such that we must travel by this road if we want to follow Jesus Christ. ${ }^{77}$

Suffering, then, was a mark of the true church and of God's chosen ones: "Saint Paul shows us by his own example that we have to glorify ourselves with the stigmata of Christ, which are the marks by which God recognizes us and acknowledges us as his own." Additionally, Calvin stated that God uses persecution to discover which are his faithful. ${ }^{78}$ The acceptance of suffering, in this and other anti-Nicodemite texts, was a key ingredient in defining God's faithful, just as it was in the general rhetoric of martyrdom.

Suffering martyrdom, however, was not for everyone. Whereas Calvin and Viret extolled martyrdom as it edified of the faithful and embodied true Christianity, ${ }^{79}$ neither advocated martyrdom wholesale. One must be willing to suffer even to the end in defense of God's honour, but it must be done carefully and correctly. Confessions were to be made with "Christian modesty," and martyrdom was not to be sought out. Both acknowledged how foreign martyrdom was to human nature, and to that extent, Calvin and Viret counselled exile as the most realistic response to the persecution. If one was forced to stay due to weakness or circumstances that could not be overcome, then they recommended steadfastness. Viret, in particular, consoled those who could not "attain to this high grade and to the Christian perfection of the martyrs...." Instead, he offers, "let us be secret disciples with Nicodemus and with Joseph of Arimathea. And if we do not show ourselves clearly, let us at least not do anything that would dishonor Jesus Christ, and let us not agree with his adversaries by sharing at the table of the devils." 80

He qualified this concession, though, with the demand that those who must do this must also confess their weakness to God and beg for his forgiveness. Viret's sentiments are echoed in Calvin's Petit traicté, though Calvin added, at the end of his recommendation, that "the glory of God, which is what is at question here, should be more precious to us than this fallen and transitory life, which, to speak truly, is no more than a shadow." 81

The choices of the faithful persecuted in France were not simply a matter that affected the individual. Reformers such as Viret and Calvin imbued these decisions with a social consciousness. Choice of behavior had communal repercussions: ranging from providing bad examples and leading others to the same sin, through bringing God's ire upon them all or physical harm upon others, to undermining the efforts of the martyrs. Just as the martyr supported and edified the community through his suffering and sacrifice to uphold the Gospel, so the Nicodemite damaged and subverted it. 


\section{Conclusion}

The breakdown of a community is often based upon difference; the creation and identification of a community, upon similarity. With the rise of Protestantism in France in the 1530s, the old institutions of Catholicism that bound the community together were challenged. Reformers insisted that the faithful abstain from any and all forms of "idolatry." In doing so, they attempted to create a separate community, one that was "pure" and untainted.

From the 1540s on, as the repression of "heresy" by the state and hostility from the predominantly Catholic populace increased, the rhetoric of martyrdom took central stage. It reassured the faithful that persecution and suffering were the mark of the true Church. The new community, then, was bound not only by their common faith but by the shared experience of suffering and sacrifice. The rhetoric, through the martyrologies and martyrological narratives, provided examples (to which all could relate) and representations that reinforced the notion that they all suffered for a common, righteous cause-counter to the accusations of blasphemy, heresy, and seduction put forth by the state. Martyrdom became a vehicle by which the Reform could re-conceptualize the past and create an interpretation of history (both ancient and contemporary) which would legitimate the new community. It was through the rhetoric of martyrdom that the Reform created a sense of universality, that the fight for which they all suffered transcended geography, time, and traditional hierarchies.

The imagery and language used in the anti-Nicodemite texts are specific examples of the rhetoric of martyrdom; they define and support a community based upon suffering and the fight against the superstitions and idolatry of their former community. Reformers such as Calvin and Viret considered it the responsibility of the faithful to support this new community rather than undermine it with human frailty or a desire for earthly comfort. To endure suffering for the cause was to bear the cross of Christ, and to avoid this cross was to deny him. The reformers imbued this argument with a social consciousness, making the faithful aware of their responsibility not only to God, but to the community as well. This was done through the same images, language, and symbols of the larger rhetoric of martyrdom.

The proper functioning of the community of the faithful was integral to the success of the Reform in the minds of many of its leaders. A shared faith, however, was not enough to psychologically and emotionally bind the persecuted community in France together. Thus, the rhetoric of martyrdom, which further defined the community through suffering, provided 
the means by which the faithful could make sense of a world of violence and dislocation.

\section{Rider University}

\section{Notes}

I would like to thank Donald Kelley, William Connell, Phyllis Mack, and John Salmon for their careful readings of an earlier draft of this essay. Additionally I thank the journal's two readers, François Rigolot and Paul Cohen, for their insightful suggestions.

1. "Les uns recognoistront ici leurs frères \& compagnons arrachez de leur compagnie, pour être cruellement mis à mort: les femmes y trouveront leurs maris, les pères leurs enfans, \& les enfans leurs pères tormentez, \& meurtris pour la parolle de Dieu. Les autres y veront le temps de leur emprisonnement, ou bien de leur suite. Les autres y entendront leurs pertes, le ravissement de leurs biens, \& la desolation de leurs familles." Antoine de la Roche Chandieu, Histoires de Persécutions, et Martyrs de l'Église de Paris, depuis l'An 1557. jusques au temps du Roy Charles neufviesme (Lyon, 1563), p. vii.

2. Theodore Beza, "Life of Calvin," in John Calvin, Tracts and treatises, vol. 1 (Edinburgh: Oliver \& Boyd, 1958), p. Ixxxvii.

3. It is important to note that not all of the Protestant reformers or writers of the period were consistently or profoundly anti-Nicodemite, though as proven by numerous scholars there was no organized movement pre-dating the persecution (per Carlo Ginzburg, Il Nicodemismo [Turin: G. Einaudi, 1970]) to spread "the message of Nicodemism." See Carlos Eire, "Calvin and Nicodemism: A Reappraisal," Sixteenth Century Journal, 10 (1979), pp. 45-69; Peter Matheson, "Martyrdom or Mission? A Protestant Debate," Archiv für Reformationsgeschichte, 80 (1989), pp. 158-165; Perez Zagorin's, Ways of Lying: Dissimulation, Persecution, and Conformity in Early Modern Europe (Cambridge, Mass.: Harvard UP, 1990), pp. 68-70.

4. See, for example, Zagorin, esp. ch. 4; Matheson, "Martyrdom or Mission?"; Carlos Eire, "Prelude to Sedition? Calvin's Attack on Nicodemism and Religious Compromise," Archiv für Reformationsgeschichte, 76 (1985); Carlos Eire, War Against the Idols: The Reformation of Worship from Erasmus to Calvin (New York: Cambridge UP, 1986), esp. ch. 7; Ginzburg, Il Nicodemismo; Eugénie Droz, Chemins de l'Hérésie: Textes et Documents (Geneva: Slatkine Reprints, 1970), pp. 131-165; Albert Autin, Un Episode de la vie de Calvin: La Crise du Nicodémisme 1535-1545 (Toulouse: P. Tissot, 1917).

5 William Bouwsma, John Calvin: A Sixteenth-Century Portrait (New York: Oxford UP, 1988), p. 216.

6. Eire, War Against the Idols, p. 264.

7. Brad Gregory, Salvation at Stake: Christian Martyrdom in Early Modern Europe (Cambridge, Mass.: Harvard UP, 1999), p. 154.

8. "Je di notre captivité, pour ce que vous devez sentir la mienne, \& moy la votre. Car tous biens \& tous maux font communs entre frères." Jean Crespin, Histoire des vrays tesmoins de la verité de l'Evangile, qui de leur sang l'ont signée, depuis Jean Hus jusques au temps presente. (Geneva, 1570 [reprint, Liége, Centre national de recherches d'histoire religieuse, 1964]), p. 182. 
9. See Origen, Exhortation to Martyrdom, in Origen: Prayer, Exhortation to Martyrdom, trans. and ed. John J. O'Meara (Westminster, Md.,: The Newman Press, 1954); Tertullian, Apology and Letter to Scapula, in Tertullian: Apologetical Works and Minucius Felix Octavius, trans. Rudolph Arbesmann, Emily Joseph Daly, and Edwin A. Quain (New York: Fathers of the Church, 1950); Tertullian, To the Martyrs, in Tertullian: Disciplinary, Moral, and Ascetical Works, trans. Rudolph Arbesmann, Emily Joseph Daly, and Edwin A. Quain (New York: Fathers of the Church, 1959).

10. "He who loves father or mother more than me is not worthy of me; and he who loves son or daughter more than me is not worthy of me; and he who does not take his cross and follow me is not worthy of me. He who finds his life will lose it, and he who loses his life for my sake will find it." (Revised Standard Version).

11. Tertullian's To the Martyrs and Letter to Scapula were translated, edited, and published together as Deux Petits Livres de Florent Tertullian (Lyon, 1564) by a Huguenot publisher.

12. For example, see Martin Luther, “Third Lenten Sermon," in Luther's Works, ed. J. Pelikan (St. Louis: H.T. Lehmann, 1955); Calvin, Petit Traicté monstrant que c'est que doit faire un homme fidèle congnoissant la vérité de l'Evangile, quand il est entre les Papistes (1543), in Ioannis Calvini Opera quae supersunt omnia, ed. Guilielmus Baum, Eduardus Cunitz, and Eduardus Reuss, vol. 6 (Braunschweig: Schwetschke and Sons, 1867), pp. 542-588, hereafter referred to as CO; Calvin, Quatre sermons de M. Iehan Calvin traictans des matières for utiles pour nostre temps (1552), in vol. 8 of $C O$, pp. 369-452; Calvin, "On Shunning the Unlawful Rites of the Ungodly and Preserving the Purity of the Christian Religion," in Calvin's Tracts and Treatises, ed. Thomas F. Torrance, vol. 3 (London: Oliver and Boyd, Ltd., 1958), pp. 359-412; Pierre Viret, Traittez divers pour l'instruction des fidèles qui resident \& conversent eslieus \& pais esquels il ne leur est permis de vivre en la pureté \& liberté de l'Évangile. Revus \& augmentez (Geneva, 1559); The views of the early reformers on idolatry are treated rather comprehensively in Eire, War Against the Idols, ch. 3, and on Calvin's views in ch. 6. Calvin however was not the first to address either Nicodemism or intolerance of idolatry. See Eire, "Prelude to Sedition?", pp. 123-125.

13. For a discussion of "pollution" in Calvin, see Bouwsma, p. 36. Not all reformers were of the same mind as Calvin regarding the "pollution" of idolatry. Gérard Roussel, Jacques Lefèvre d'Etaples, and other French Humanist reformers were accused of Nicodemism by Calvin for their attempt to reform the church from within. See Zagorin, pp. 71, 75.

14. For examples see Calvin, Excuse de Jehan Calvin, in vol. 6 of CO, p. 611, and Jean L'Espine, Traitté consolatoire et fort utile, contre tous afflictions qui adviennent ordinairement aux fidèles Chrestiens (Lyon, 1565), pp. 7-8.

15. Calvin, "Letter of 1540," in vol. 11 of $C O$, p. 56, cited in Bouwsma, p. 36.

16. Calvin, Petit traicté, in vol. 6 of $C O$, p. 557.

17. Pierre Imbart de la Tour, Les origines de la Réforme, vol. 4 (Geneva: Slatkine Reprints, 1978), p. 98.

18. See below. The martyrs or "prisoners for the cause" also admonished the faithful to attend. See, for example, "Exhortation d'un Evesque de France au troupeau de son diocese, qui ha receu la réformation de 1'Evangile," (S.L., 1561), in Ample Discours des acts memorables des Poissy (S.L, 1561).

19. For example, see Pierre Viret, "Epistre envoyée aux fidèles," Traittez divers, p. 15. This particular passage is quoted by numerous reformers in many different treatises. See for example, Conseilz et Advis de Plusieurs Grands \& doctes personnages sus 
la même matière contenue au précédent Livre du Temporiseur, ed. Jean Saugrain (Lyon, 1565), especially Celius Secundus, Oecolampadius, and Melanchthon.

20. David Nichols, "The Theatre of Martyrdom in the French Reformation," Past and Present, 121 (1988), p. 68.

21. Donald R. Kelley, Beginning of Ideology: Consciousness and Society in the French Reformation (New York: Cambridge UP, 1981), p. 96.

22. "Entre les marques de la vraye Eglise de Dieu, ceste cy a été l'un des principales, à savoir, qu'elle a de tous temps soustenu les assaux des persécutions." Crespin, p. iii.

23. "Vous pourrez distribuer lesdites lettres aux uns \& aux autres, afin qu'il en revienne plus grand fruict à l'Eglise.” Crespin, p. 236.

24. "Nous l'avons ici mis [his letters] pour en faire participan tous fidèles."Crespin, p. 277.

25. "J'en reciteray aucune chose, estimant que ne le requerez par curiosité: mais seulement pour l'edification de l'Eglise." Crespin, p. 279.

26. For a discussion of English martyrs's letter writing and community, see John R. Knott, Discourses of Martyrdom in English Literature, 1563-1694 (New York: Cambridge UP, 1993), ch. 3.

27. Donald W. Riddle, The Martyrs: A Study in Social Control (Chicago: U of CP, 1931), p. 106.

28. For example, see Chandieu, pp. xviij-xix, and Crespin, p. 58.

29. See Phyllis Mack Crew, Calvinist Preaching and Iconoclasm in the Netherlands, 1544-1569 (New York: Cambridge UP, 1978), p. 113, for an analysis of the continuity of the community of suffering in the Dutch Reform.

30. "Perpetuelles embuchés, pratiques \& tormens." Heinrich Bullinger, Deux Sermons de la Fin du siècle (Geneva, 1557). It is interesting to note here that this pamphlet was published by Jean Crespin.

31. Crespin, "Preface," Histoire des vrays tesmoins. See also Chandieu, p. xxxiij.

32. Tertullian, Deux petis Livres, pp. 3-4.

33. For an analysis of the metaphor of the Christian soldier in the rhetoric of martyrdom in English martyrologies, see Knott, Discourses of Martyrdom, pp. 99-101.

34. See, for example, Declaration et Protestation de ceux de la Religion Reformée de la Rochelle sur la prise \& capture des armes qu'ils ont fait le neufiseme de Janvier dernier (S.L., 1568).

35. See Prières pour les soldats \& prisonniers de l'Eglise reformée (La Rochelle, 1568).

36. "Vaillans champions, qui ont passé par leur combats, \& par leur mort surmonte toutes afflictions, sont merveilleusement utiles \& necessaires." Crespin, "Preface," Histoire des vrays tesmoins.

37. "Sus donc, mes compagnons de guerre, à l' assaut. courage, soldats, courage, marchez hardiment. Ne les craignez point. ils ne sont pas gens pour nous: car Jesus Christ notre capitaine nous les a tous vaincus. L'esperance donc sa victoire nous servira d'armer notre teste. N'oublions pas notre bouclier, qui est d'avoir une foi vive, puissante \& vertueuse, pour repousser les coups de nos ennemis. Gardons que l'espée ne nous eschappe de la main. ce cousteau de sainct Esprit tranchant des deux costez, qui est cest vive parolle de Dieu, laquelle perce \& coeurs \& ames, \& pensées \& intentions." Crespin, p. 183. 
38. "Sous la protection, \& deffense duquel nous devons tous batailler, comme vrays champions, \& fidèles soldats de notre Capitaine." Chandieu, p. 167.

39. 'Pensons aussi que ce n'est pas grand honneur d'un Chrestien, si quand il part de ce monde, pour retourner au ciel, revoir son père, il ne lui porte son bouclier, qui est la foi, \& sa lance qui est la parolle, \& universallement toutes ses armes roughes, \& teintes, tant de son sang, que de celui des ennemis de l'Eglise qu'il n'y a point de plus bel ordre de Chevalier." Jean L'Espine, Traitté consolatoire, p. 20.

40. For example, see Viret, "De la communication que ceus qui cognoissent la verité de l'Evangile, aux ceremonies des papistes, \& principallement a leurs Baptesmes, Mariages, Messes, Funerailles, \& Obseques pour les trespassez," Traittez divers, pp. 209-211, on the examples of Pierre of Alexandria and Meletius of Thebiade; Calvin, Petit traicté, in vol. 6 of CO, p. 544, on Saint Cyprian and p. 570, on the Maccabees.

41. While the Edict of Paris (1535), written in the aftermath of the Affair des Placards, imposed harsh penalties upon heretics and those who harbored them, it wasn't until the Edict of Fontainbleau (1540) that the crime of heresy became elevated to high treason against both God and the state. As such, heresy trials became the jurisdiction of the Parlements, rather than solely that of the ecclesiastic courts. Hence, this edict marks the beginning of the official active involvement of the state, rather than acting in an assistant role to the ecclesiastical courts, in prosecuting and hunting down Protestants in France. It is important to note, however, the existence of the Edict of Paris (1538) in which the Parlement of Toulouse was granted authority to conduct trials for heresy, though this was only on a local level.

42. In Petit Traicté, Calvin differentiates between "dissimulation," which is acceptable, and "simulation," which is not. Dissimulation involves withdrawing from the idolatrous community while not trumpeting one's beliefs down the avenues. Simulation is Nicodemism-attending idolatrous ceremonies and pretending to accept their beliefs while secretly holding the doctrine of the Gospel in one's heart.

43. Ginzburg, in his Il Nicodemismo, argues for a cohesive and unified Nicodemite movement across Europe. Many recent scholars, however, have argued against this approach and instead describe Nicodemism as a "fearful and disorganized reaction to persecution, or the result of half-hearted evangelism" (Eire, War Against the Idols, p. 239.).

44. For the publishing history of these texts, see Droz, pp. 131-177, though she overlooks the Quatre Sermons and Reponse à un certain holandois.

45. Although the first of his major French treatises was not published until 1543 (Petit traicté monstrant que doit faire un homme fidèle), Calvin did compose at least two others in Latin during the 1530s: "De fugiendis impiorum illicitis sacris" (1536) and "De sacerdotio papale" (1536). The minor work "On Shunning the Unlawful Rites of the Ungodly and Preserving the Purity of the Christian Religion," was also published during the 1530s (1537). Calvin responded to complaints of his unreasonable demands in Excuse de Jehan Calvin, a year after the Petit traicté (1544). The Petit traicté and Excuse de Jehan Calvin were then published together in 1545. In the interim period of 1545-1552, Latin editions and other vernacular translations (German, English) of his works were published. In 1552 Quatre Sermons was published followed by Reponse à un certain holandois, lequel sous ombre de faire les chrestiens tout spirituels, leur permettent de polluer leurs corps en toutes idolatries in 1562.

46. Calvin, Excuse de Jehan Calvin, in vol. 6 of CO, p. 597. This was, in all likelihood, a reference to the humanist reformers such as Roussel, who would not break with Rome and retained his benefices. Calvin also implied financial motivation for their 
Nicodemism. Florimond de Raemond noted the antagonism that Calvin developed for Roussel and points to him as the inspiration for some of Calvin's anti-Nicodemite works. See Florimond de Raemond, L'Histoire de la Naissance, progrez, et decadence de l'hérésie de ce siècle (Aras, 1611), p. 1261.

47. Calvin, Excuse de Jehan Calvin, in vol. 6 of CO, pp. 598-99. See Eire, "Prelude to Sedition?", p. 125.

48. Calvin, Excuse de Jehan Calvin, pp. 600-2.

49. The first of the treatises, originally entitled "Epistre envoyée aux fidèles conversans entre les chrestiens Papistiques, pour leur remonstrer comment ilz se doyvent garder d'estre souillez et polluz par leurs superstitions et idolatries et de deshonorer Jesus Christ par icelles," was published in 1543 and underwent revisions for inclusion in the Traittez divers. The second treatise was "De la communication des fidèles qui cognoissent la verité de l'Evangile, aux ceremonies des Papistes, et principalesment à leurs Baptesmes, Mariages, Messes, Funerailles, et Obseques pour les trespassez," which again was revised and enlarged for the larger work. Part three of Traitez divers was the only original work in the collection. "Admonition et consolation aux fidèles, qui deliberent de sortir d'entre les Papistes pour eviter idolatrie contre les tentations qui leur peuvent advenir, et les dangers ausquelz ils peuvent tomber en leur yssue," the fourth treatise in the work, was originally published independently in 1559. "Remonstrances aux fidèles qui conversent entre les Papistes; et qui ont offices publiques touchant les moyens qu'ils doivent tenir en leur vocation, à l'exemple des anciens serviteurs de Dieu," (1547) made up the fifth treatise, though it too was revised. See Robert Dean Linder, The Political Ideas of Pierre Viret (Geneva: Droz, 1964) for an annotated bibliography of Viret's works.

50. Viret, "Epistre envoyée aux fidèles," Traittez divers, pp. 19, 20, 22.

51. Viret, "Epistre envoyée aux fidèles," p. 17.

52. Viret, "Epistre envoyée aux fidèles," pp. 18-19.

53. Zagorin, p. 105, cites Viret from the English translation, An Epistle to the Faithfull, Necessary for All the Children of God; Especially in These Daungerous Dayes (London, 1582), G4.

54. Eugénie Droz criticizes Calvin's severity and claims that his "reasons are not doctrinal but moral, and, as such, inadequate" (Chemins de l'Hérésie, pp. 154-155, 169). Calvin himself points out this criticism in the title to his work, Excuse de Jehan Calvin à Messieurs les Nicodemites sur la complaincte qu'ils font de sa trop grand'rigueur (1544), and in the text when he addresses the accusation that he can criticize because he is so far away. See Excuse de Jehan Calvin, in vol. 6 of CO, p. 606. See also Calvin's letter of September 1540 in which he himself begins to question his strong admonitions, in Herminjard, Correspondance des Réformateurs, 9 vols. (Geneva: H. Georg, 1866-97), vol. 6, p. 304.

55. For a good synopsis of Nicodemite arguments, see Zagorin, pp. 70, 72-74. On the existence of Nicodemites, see Eire, "Prelude to Sedition," pp. 142-43.

56. See Droz, pp. 173-185.

57. On Calvin's interpretation of community, see Bouwsma, pp. 201-202.

58. See Bouwsma, p. 216. Bouwsma describes how a church was "first of all a community of faith" and a "functioning community" for Calvin, and the significance of communal worship in his thought. 
59. "Car je puis protester en verité, devant Dieu et ses anges, que mon intention n'est pas autre, que de procurer, entant qu'en moi est, que nous servions Dieu tous ensemble purement." Calvin, Excuse de Jehan Calvin, in vol. 6 of CO, p. 596.

60. "C'est de ne point donner cause à notre prochain d'estre mal edifié de nous, de ne luy point donner mauvais exemple, de ne rien dire ne faire pour les desbaucher." Calvin, Petit traicté, in vol. 6 of CO, p. 563.

61. "Car notre confession precedente, $\&$ le tesmoignage publique de notre foi, donneroit floire à Dieu, \& condamneroit les idolatres, \& fortifieroit les fidèles, \& osteroit toute occasion de scandale aus bons. . . ."Viret, "Epistre envoyée aux fidèles," Traittez divers, p. 109.

62. “...un venin tant puant, $\&$ tant dangereux, que il soit qu' on se reculle de lui, tant qu'il est possible." Viret, "Epistre envoyée aux fidèles," p. 7.

63. "Il nous pousse encore à induire les autres, à faire le semblable." Viret, "Epistre envoyée aux fidèles," p. 7.

64. "Induisent les autre par leur exemple à idolatrer." Calvin, Excuse de Jehan Calvin, in vol. 6 of $C O$, p. 598.

65. "Ne scandalizent ilz pas les infirmes, leur donnant mauvais exemple, ou les mettant en doubte et scrupule, qu'ilz ne savent que juger." Calvin, Petit traicté, in vol. 6 of $C O$, p. 569.

66. Calvin, "On Shunning the Unlawful Rites of the Ungodly," pp. 374-375.

67. See also Viret, "De la communication," Traittez divers, p. 38.

68. "Et n'est pas peu de chose de donner mauvais exemple à ses prochains, pour confermer les ignorans en erreur et troubler les infirmes, ou les scandalizer! Mais quand avec tout cela nous adioustons une impudence, et que comme paillardes effrontées, nous nous torchons la bouche, pour dire que nous n'avons rien fait de mal: c'est despiter Dieu apertement, et quasi de propos deliberé le provoquer au combat, et l'armer à faire vengeance contre nous." Calvin, Excuse de Jehan Calvin, in vol. 6 of $C O$, p. 612.

69. Calvin, Petit traicté, in vol. 6 of CO, p. 564: "Finalment ils [Nicodemites] conferment les incredules, et les endurcissent en leurs erreurs."

70. "Et qui plus est, nous [who might embrace Nicodemism] enflambons la fureur des tyrans, \& trahissons nos frères, \& sommes cause souventesfois, qu'il sont mis à mort. Car si nous nous declairions d'avantage, ou pour le moins, si nous ne faisions rien pour approuver la fausse religion des idolatres, nous leur serions en confusion, au lieu que nous les confermons en leur erreur \& tyrannie, \& les armons de notre authoritie contre nos frères." Viret, "De la communication," Traittez divers, p. 38.

71. "En nourrissant toute idolatrie par leur feintise, ilz sont cause de faire rompre le col aux uns, et de faire blesser griefvement les autres, de faire cheoir les uns, et de faire clocher les autre, ou de s'esgarer hors du droict chemin." Calvin, Petit traicté, in vol. 6 of $C O$, p. 564.

72. "Les pays où il y a grande semence de Dieu, demeureoyent desert." Calvin, Petit traicté, p. 564. This is a reference to Tertullian's oft quoted, "The blood of the martyrs is the seed of the church."

73. See Calvin, Petit traicté, pp. 570, 573-74.

74. "S'ils eussent été autant craint leur peau que nous craignons la notre, la religion chrestienne ne'eust pas été tant augmentée, en si peu de temps." Viret, "Epistre aux Fidèles," Traittez divers, p. 120. 
75. Calvin, Excuse de Jehan Calvin, in vol. 6 in CO, p. 604.

76. "Et pourtant, qui veut être mon disciple, il faut qu'il renonce soy-meme, \& qu'il porte tous les jours sa crois sur ses espaules, \& qu'il me suive." Viret, "Epistre aus Fidèles," pp. $15-16$.

77. "Ja soit que cela nous semble rude de prime face, si nous debvrions-nous bien contenter de ce mot de sainct Paul (1 Thess. 3, 3), c'est que nous sommes appelez et establis à souffrir: comme s'il disoit que la condition de nostre Chrestienté est telle, en sort qu'il nous fault passer par ce chemin, si nous voulons suyvre Iesus Christ." Calvin, "Exhortation de souffrir," Quatre Sermons, in vol. 8 of CO, p. 397.

78. "Sainct Paul nous monstre par son exemple que nous avons à nous glorifier aux fletrisseures de Iesus Christ, comme aux marques esquelles Dieu nous recognoist et advoue par siens." Calvin, "Exhortation de souffrir," p. 404.

79. See Calvin, "Exhortation de souffrir," pp. 403-404; and Viret, "De la communication," Traittez divers, pp. 209-211.

80. "Parvenir à ce haut degre, \& à cest perfection chrestienne des Martyrs . . . Soyons des disciples secrets avec Nicodeme \& avec Joseph d'Arimathie. Et si nous ne manifestons pas clairement, ne faisons point, pour le moins, de deshonneur à Jesus Christ, \& ne consentons point avec ses adversaires, en participant à la table des diables." Viret, "Epistre aux fidèles," Traittez divers, p. 121. It is interesting here to note that here Viret views acting as Nicodemus in a positive light versus his more derogative use of the term Nicodemite in other places.

81. "La gloire de Dieu, de laquelle il est ici question, nous doit bien estre plus precieuse que ceste vie caduque et transitoire: qui n'est à dire vray, fors qu'une numbre." Calvin, Petit traicté, in vol. 6 of CO, p. 576. 